Mahmoud Enieb Osman et al., The optimum airport runway orientation for different regions in Egypt, pp. $2126-2139$

\title{
THE OPTIMUM AIRPORT RUNWAY ORIENTATIONFOR DIFFERENT REGIONS IN EGYPT
}

\author{
El-Sayed Mohamed Abdalla ${ }^{1}$, Mahmoud Enieb Osman ${ }^{2, *}$ \\ and Ramy Nasr Abd El-monem Mohamed ${ }^{3}$ \\ ${ }^{1,2}$ Staff in Civil Engineering Department, Faculty of Engineering, Assiut University, Assiut, Egypt \\ ${ }^{3}$ Project control Engineer, American International Contractors, AICI, Egypt
}

Received 22 October 2013: accepted 19 November 2013

\begin{abstract}
This study investigates wind analysis which is conducted by manual analysis and computer analysis for airports outside population settlements. The accuracy of used software in computer analysis was checked by comparing their results with the manual procedure. The manual analysis represented by windrose type II while the computer analysis represented by two software the Federal Aviation Administration (FAA) Airport design and windrose PRO. Wind patterns of twenty regions in Egypt are examined by WORPLOT View and FAA Airport Design program to estimate the best runway orientation. These twenty regions have thirteen regions with existing airports and seven regions of bearable airports. After examining Egyptian surface wind pattern found that the optimum solution for the most of Egypt regions is one direction while there are two directions for Mersa Matruh and Port Said. The existing runways in Assiut airport and Port Said airport have not fulfill standard requirement which were taken in this study (wind coverage and cross wind rules) throughout the year. Runway orientation was found for previousexamined airports. Three runway orientations had been studied with more details, Aswan, Marsa Alam and Al Nozha airports.There is one proposed runway in Al Nozha airport, which have fulfilled standard requirement throughout the year instead of the existing runways. Aswan and Marsa Alam existing runways were accepted.
\end{abstract}

Keywords: Airport, runway, orientation, wind analysis, FAA software

\section{Introduction}

The runway orientation is an important factor in efficiency and safety consider in airports. The runway configurations, runway length, runway width, location of terminal area and runway numbering depend on it. Desirable runway was orientated based on wind direction, crosswind component and wind coverage. Runway is always oriented in the direction of prevailing wind. For safety of the maneuver operation the runway should be oriented to have the largest wind coverage and minimum cross wind component [1]. Another wind component has some effect on aircraft operation during its landing and takeoff is the head wind. The head wind opposite to the direction of landing and takeoff provides greater lift on the wings of the aircraft when it taking off that making the aircraft rises above the ground much earlier than requiring short length of the runway. During landing the headwind provides a breaking effect due to the drag developed by friction between aircraft fuselage and the air. Many factors should be taken into account in the determination of the sitting and orientation of runways. An accurate analysis of wind is essential to determine the orientation and number of runways in any airport in order to give the desired wind coverage depending on the planed airport and its related maximum allowable crosswind, $[2,3,4,5]$. This study is to analysis local wind data provided by Egyptian meteorological

* Corresponding author.

E-mail address:m.enieb@aun.edu.eg 
Mahmoud Enieb Osman et al., The optimum airport runway orientation for different regions in Egypt, pp. 2126 - 2139

organization and surface synoptic observations (SYNOP) reports in the different areas in Egypt. The best runway orientation for the studied cases was found.

\section{Objective and Proposed Methodology}

In order to achieve the objectives of this study some steps were conducted as shown in Figure 1. These analyses are conducted through the use of Windrose II technique, FAA airport design program and windrose PRO program. Then several results are going to be compared and verified as following:-

1-To compare the results of the manual wind analysis results calculated by the use of Windrose II technique withthe results of FAA Airport design and windrose PRO programs. These comparisons were performed to investigate each program capability of selecting optimum airport runway orientation.

2-Conducting operational analysis to the existing runways systems in local cases studies by calculating wind coverage of their orientation.

3-To conduct parametric study for each local case study.

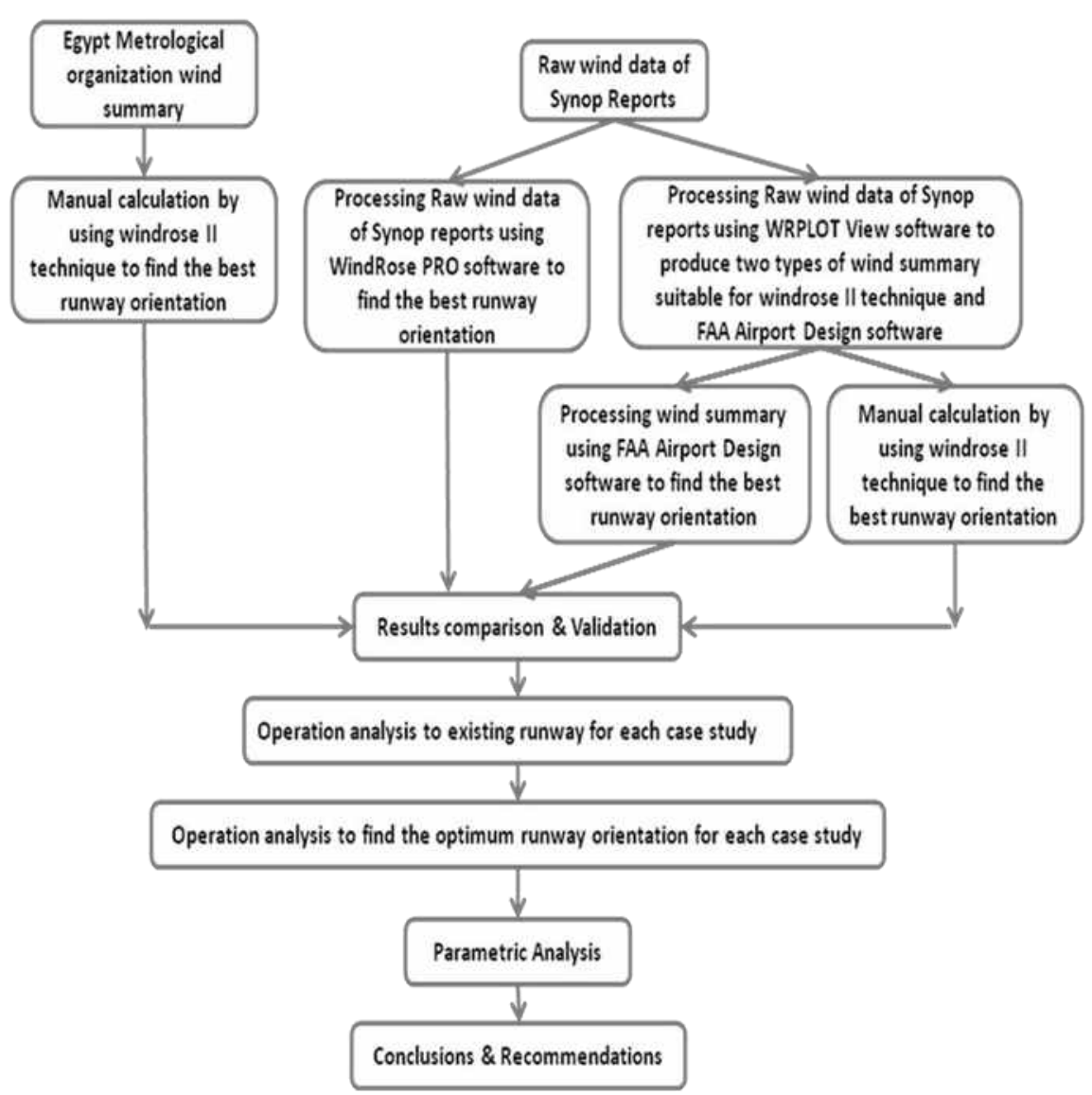

Fig. 1. Research structure diagram.

Journal of Engineering Sciences, Assiut University, Faculty of Engineering, Vol. 41, No. 6, November, 2013,E-mail address: jes@aun.edu.eg 
Mahmoud Enieb Osman et al., The optimum airport runway orientation for different regions in Egypt, pp. 2126 - 2139

\section{Wind Characteristics}

Airport planners and designers should make an accurate analysis of wind to determine the orientation and number of runways because of its important role on them. The results of this analysis will add substantially to the safety and usefulness of the airport. The most desirable direction of runways can be determined by examination of the wind characteristics for different components such as cross wind, wind coverage, tailwind, headwind, gusting winds, turbulence and wind shear. Crosswind and wind coverage are the most important wind factors affect the optimum runway orientation $[2,3,4,5]$. Therefore the study of the effect of wind to fix runway orientation is illustrated in the following:

\subsection{Crosswind}

A crosswind is any wind that is blowing perpendicular to a line of travel, or perpendicular to a direction of runway. In aviation, a crosswind is the component of wind that is blowing across the runway making a landing more difficult than if the wind were blowing straight down the runway. If a crosswind is strong enough it may exceed an aircraft's crosswind limit and an attempt to land under such conditions could cause structural damage to the aircraft's undercarriage. When winds are neither perpendicular nor parallel to the line of travel, the wind is said to have a crosswind component; that is can be separated into two components, a crosswind component and a headwind or tailwind component. The crosswind component is computed by multiplying the wind speed by the sine of the angle between the wind and the direction of travel as shown in Figure 2.

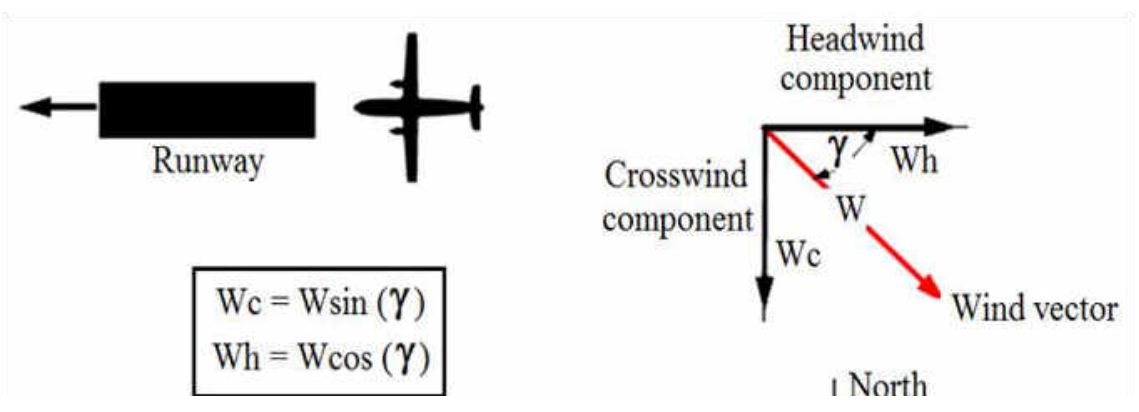

Fig. 2. Cross wind component, [5].

\subsection{Wind coverage}

The most desirable runway orientation is the one which has the largest wind coverage and minimum crosswind components. Wind coverage is that percent of time crosswind components below an acceptable velocity. The desirable wind coverage for an airport is 95 percent based on the total number of weather observations. This value of 95 percent takes into account various factors influencing operations and the economics of providing the coverage [4]. FAA and the International Civil Aviation Organization (ICAO) have established their design standards that recommend a runway in the direction of prevailing

Journal of Engineering Sciences, Assiut University, Faculty of Engineering, Vol. 41, No. 6, November, 2013, E-mail address: jes@aun.edu.eg 
Mahmoud Enieb Osman et al., The optimum airport runway orientation for different regions in Egypt, pp. 2126 - 2139

winds andits orientationallows aircraft's takeoff and/or land at least $95 \%$ of the time without exceeding the allowable crosswinds [2, 3, 4, 5, 6, and 7].

\subsection{Wind data}

In order to carry out proper wind analysis, a record which covers the last 10 consecutive years of wind observation is preferred. Wind data records usually consist of observations taken regularly every hour. Each observation includes apart from wind speed \& direction, the cloud \& visibility and air temperature \& pressure. Wind data are usually collected and processed in many ways according to their needs. Generally they are classified according to the direction and speed [2,3,4,5].SYNOP is a numerical code used for reporting weather observations made by manual and automated weather stations. These reports were used to prepare wind statistics for each case study $[8,9,10]$.

\subsection{Analyzing wind data}

Wind information could be analyzed in many ways, either manually or by using computer programs. The manual procedure which uses a graphical presentation of this information consists of two main types of windrose. While on the other hand, the computer programs can be analyzed wind to draw windrose and examining wind data to find the optimum runway orientation, [2, 3, 4, 11, 12, and 13].

\section{Cases Studies}

Wind patterns of twenty regions in Egypt are examined by WORPLOT View and FAA airport design program to estimate the best runwayin different regions in Egyptshown in Figure 3. These twenty regions have thirteen regions with existing airports and seven regions of bearable airports. Wind observation was examined for each case $[13,14,15,16]$.

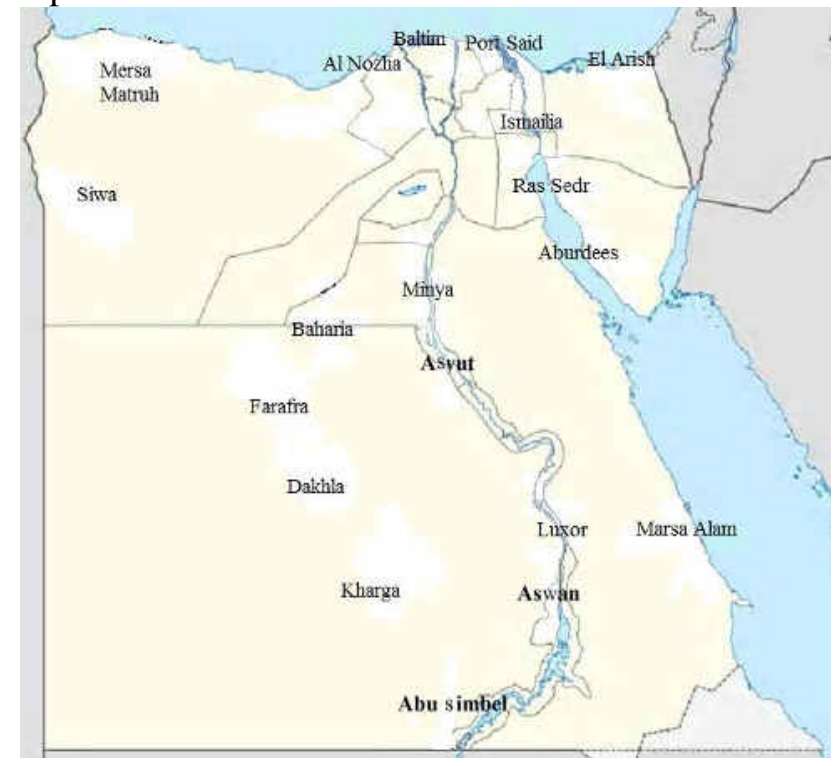

Fig. 3. Map show studying regions in Egypt, [1].

Journal of Engineering Sciences, Assiut University, Faculty of Engineering, Vol. 41, No. 6, November, 2013,E-mail address: jes@aun.edu.eg 
Mahmoud Enieb Osman et al., The optimum airport runway orientation for different regions in Egypt, pp. $2126-2139$

\section{The Used Computer Programs Applications}

The computer programs WRPLOT view software applications was used for collecting wind data to find the optimum runway orientation with windrose PRO software, FAA airport design and Windrose II technique as follows:

\subsection{WRPLOT view software applications}

WRPLOT View developed to produce graphic plots of windrose and windrose Statistics. A wind rose depicts the frequency of wind directions and wind speed for a given location and time period.WRPLOT View software is used to estimate the wind resultant vector which helps to find the direction of the runway setting into prevailing wind direction.

\subsection{FAA airport design software application}

TheFAA airport design software is used to find the optimum runway orientation for each case study.Thedata of wind summary that produced by analysis raw wind data of SYNOP reports is analyzed with WRPLOT View software.Then wind data information and the available cross wind component will be filled in the FAA airport design software. The runway orientation degree will be filled with different degrees to obtain the maximum wind coverage. After many tries of runway orientation degree for examining airports, the best runway orientations are shown in Table 1 and Figure 4.

Table 1.

Best runway orientation for various regions in Egypt.

\begin{tabular}{|c|c|c|c|c|c|}
\hline No. & $\begin{array}{c}\text { Egypt } \\
\text { region }\end{array}$ & $\begin{array}{c}\text { Best runway } \\
\text { orientation }\end{array}$ & $\begin{array}{c}\text { Wind } \\
\text { coverage }\end{array}$ & $\begin{array}{c}\text { Runway } \\
\text { designation }\end{array}$ & $\begin{array}{c}\text { Existing } \\
\text { Runway } \\
\text { designation }\end{array}$ \\
\hline 1 & Minya & $165 / 345$ & $99.61 \%$ & $16 / 34$ & $16 / 34$ \\
\hline 2 & Kharga & $5 / 185$ & $99.85 \%$ & $18 / 36$ & $18 / 36$ \\
\hline 3 & Siwa & $130 / 310$ & $99.20 \%$ & $13 / 31$ & ------- \\
\hline 4 & Abu & $05 / 185$ & $98.01 \%$ & $18 / 36$ & $15 / 33$ \\
\hline 5 & Aburdees & $150 / 330$ & $98.73 \%$ & $15 / 33$ & $13 / 31$ \\
\hline 6 & Assuit & $165 / 345$ & $97.91 \%$ & $16 / 34$ & $13 / 31$ \\
\hline 7 & Baharia & $170 / 350$ & $99.85 \%$ & $17 / 35$ & ------- \\
\hline 8 & Baltim & $160 / 340$ & $99.02 \%$ & $16 / 34$ & -------- \\
\hline 9 & Dakhla & $150 / 330$ & $99.82 \%$ & $15 / 33$ & $15 / 33$ \\
\hline 10 & El Arish & $160 / 340$ & $98.58 \%$ & $16 / 34$ & $16 / 34$ \\
\hline 11 & Ismailia & $165 / 345$ & $95.17 \%$ & $16 / 34$ & ------- \\
\hline 12 & Luxor & $145 / 325$ & $99.89 \%$ & $14 / 32$ & $02 / 20$ \\
\hline
\end{tabular}

Journal of Engineering Sciences, Assiut University, Faculty of Engineering, Vol. 41, No. 6, November, 2013, E-mail address: jes@aun.edu.eg 
Mahmoud Enieb Osman et al., The optimum airport runway orientation for different regions in Egypt, pp. $2126-2139$

\begin{tabular}{|c|c|c|c|c|c|}
\hline No. & $\begin{array}{c}\text { Egypt } \\
\text { region }\end{array}$ & $\begin{array}{c}\text { Best runway } \\
\text { orientation }\end{array}$ & $\begin{array}{c}\text { Wind } \\
\text { coverage }\end{array}$ & $\begin{array}{c}\text { Runway } \\
\text { designation }\end{array}$ & $\begin{array}{c}\text { Existing } \\
\text { Runway } \\
\text { designation }\end{array}$ \\
\hline 13 & $\begin{array}{c}\text { Mersa } \\
\text { Matruh }\end{array}$ & $\begin{array}{c}145 / 325 \\
, 70 / 250\end{array}$ & $97.43 \%$ & $14 / 32,07 / 25$ & $15 / 33,06 / 24$ \\
\hline 14 & Farafra & $165 / 345$ & $99.05 \%$ & $16 / 34$ & -------- \\
\hline 15 & Port Said & $\begin{array}{c}155 / 335 \\
, 65 / 245\end{array}$ & $99.44 \%$ & $15 / 33,06 / 24$ & $10 / 28$ \\
\hline 16 & Ras Sedr & $155 / 335$ & $99.76 \%$ & $15 / 33$ & -------- \\
\hline 17 & $\begin{array}{c}\text { Wadi El } \\
\text { Natroon }\end{array}$ & $150 / 330$ & $98.9 \%$ & $15 / 33$ & -------- \\
\hline 18 & Aswan & $174 / 354$ & $98.2 \%$ & $17 / 35$ & $17 / 35$ \\
\hline 19 & Al Nozha & $146 / 326$ & $96.04 \%$ & $15 / 33$ & $18 / 36,04 / 22$ \\
\hline 20 & $\begin{array}{c}\text { Marsa } \\
\text { Alam }\end{array}$ & $156 / 336$ & $99.72 \%$ & $16 / 34$ & $15 / 33$ \\
\hline
\end{tabular}

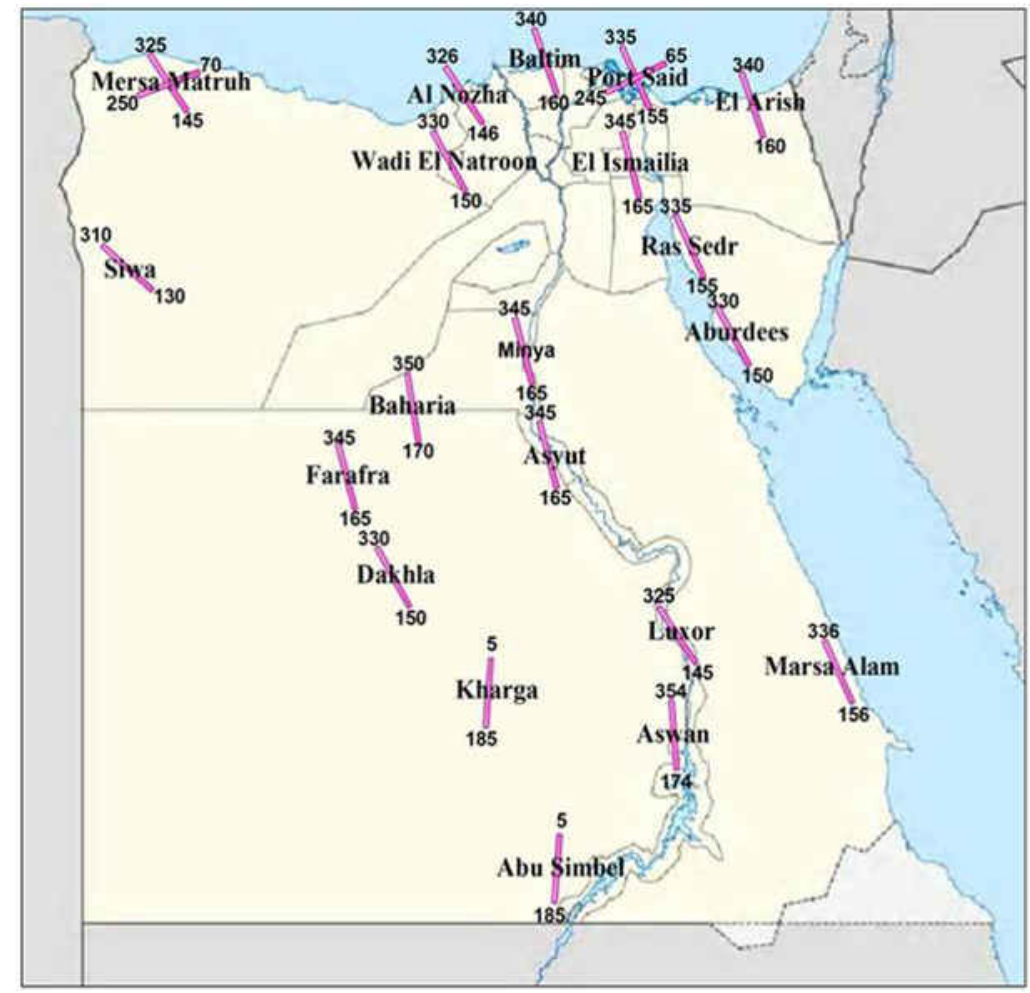

Fig.4. Map show the best runway orientation for various regions in Egypt.

Journal of Engineering Sciences, Assiut University, Faculty of Engineering, Vol. 41, No. 6, November, 2013, E-mail address: jes@aun.edu.eg 
2132

Mahmoud Enieb Osman et al., The optimum airport runway orientation for different regions in Egypt, pp. 2126 - 2139

The existing runways in Assuit airport and Port Said airport have not acceptable orientation considered specification requirements. For Assuit airport the existing runway designation is $13 / 31$ provides $91.60 \%$ wind coverage while the optimum runway designation is $16 / 34$ provides $97.91 \%$ wind coverage. For Port Said airport existing runway designation is $10 / 28$ provides $89 \%$ wind coverage while the optimum solution is two directions with runways designation of $15 / 33 \& 06 / 24$ provides $99.44 \%$ wind coverage. Bearable airport runway orientation Siwa Oasis is designation $13 / 31$ provides $99.20 \%$ wind coverage. Baharia Oasis is designation $17 / 35$ provides $99.85 \%$ wind coverage. Baltim is designation $16 / 34$ provides $99.02 \%$ wind coverage. Ismailia is designation 16/34 provides $95.17 \%$ wind coverage. Farafra Oasis is designation $16 / 34$ provides $99.05 \%$ wind coverage. Ras Sedr is designation $15 / 33$ provides $99.76 \%$ wind coverage. Wadi El Natroon is designation $15 / 33$ provides $98.90 \%$ wind coverage.

Aswan and Al Nozha SYNOP reports wind observations for years of 2006, 2007, 2008 and Marsa Alam wind observations for year 2006 produced by Marsa Alam airport organization are processing by WRPLOT View software and produced suitable two types of wind summaries for FAA airport design software and Windrose II technique for each case study. The wind resultant vector for Aswan airport, Al Nozha airport and Marsa Alam airport is near the north direction and has degree of 356, 336 and 336 respectively as shown in Figure 5. Figure 6 shows the wind rose for Aswan station, Al Nozha station and Marsa Alam station produced by Egyptian meteorological organization for period of 40 years.

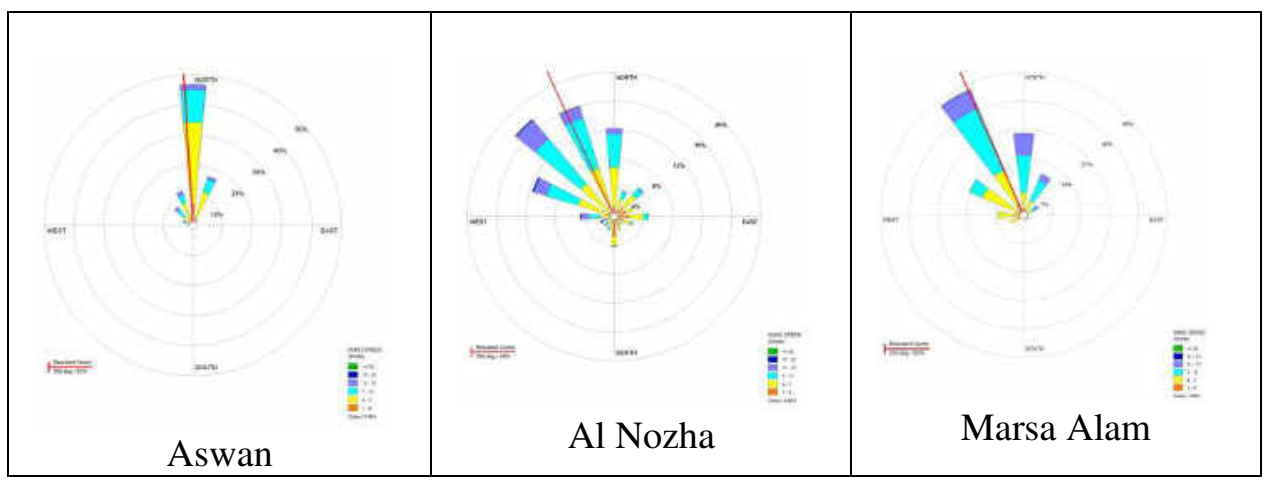

Fig.5. Aswan, Al Nozha and Marsa Alam airports wind rose produced by WRPLOT view software.

Journal of Engineering Sciences, Assiut University, Faculty of Engineering, Vol. 41, No. 6, November, 2013, E-mail address: jes@aun.edu.eg 
Mahmoud Enieb Osman et al., The optimum airport runway orientation for different regions in Egypt, pp. $2126-2139$

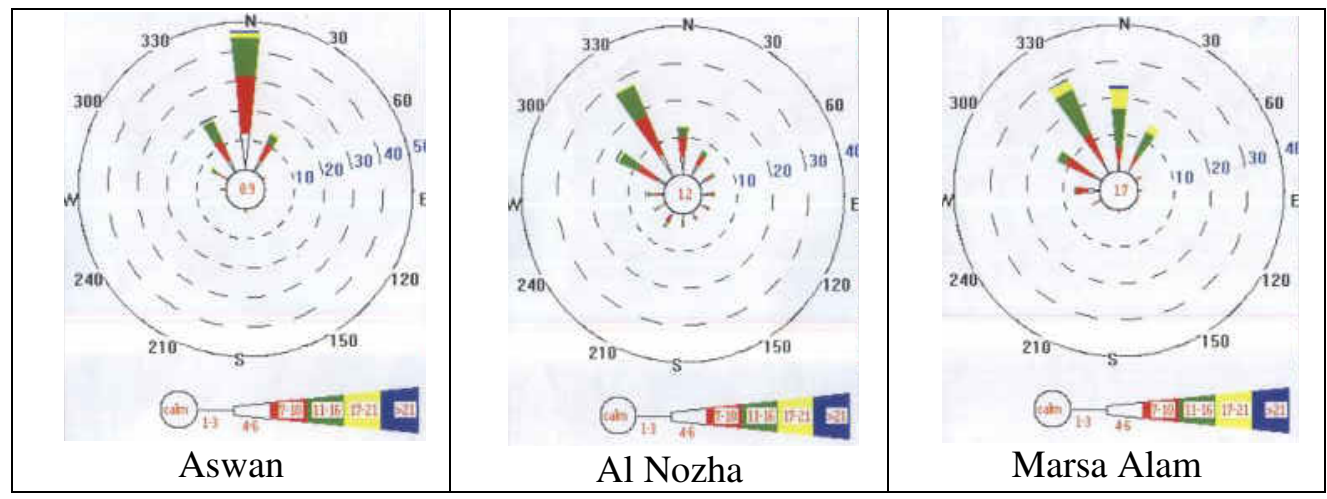

Fig. 6. Aswan, Al Nozha and Marsa Alam airports wind rose produced by Egyptian meteorogical organization.

\subsection{Windrose PRO software application}

WindRose PRO is a Windows application for representing directional variables starting from raw data or from their frequencies like windroses and it also used for selecting the best runway orientation. In order to find the optimum runway orientation for each case study, raw wind data provided by Aswan and Al Nozha Synop reports and the raw wind data produced by Marsa Alam airport organization will be saved in suitable Excel format for windrose PRO software. This Excel format will be loaded in windrose PRO software. The design crosswind component and angular step of runway orientation will be specified. After reviewing the output data for Aswan international airport it is found that the best runway orientation is $175 / 355$, wind coverage is $97.89 \%$ and runway designation is $17 / 35$ as shown in Figure 7. After reviewing the output data for Al Nozha international airport it is found that the best runway orientation is $145 / 325$, wind coverage is $96.311 \%$ and runway designation is 14/32 as shown in Figure 8. After reviewing the output data with KML file data for Marsa Alam international airport it is found that best runway orientation is $155 / 335$, wind coverage is $95.821 \%$ and runway designation is $15 / 33$ as shown in Figure 9 .
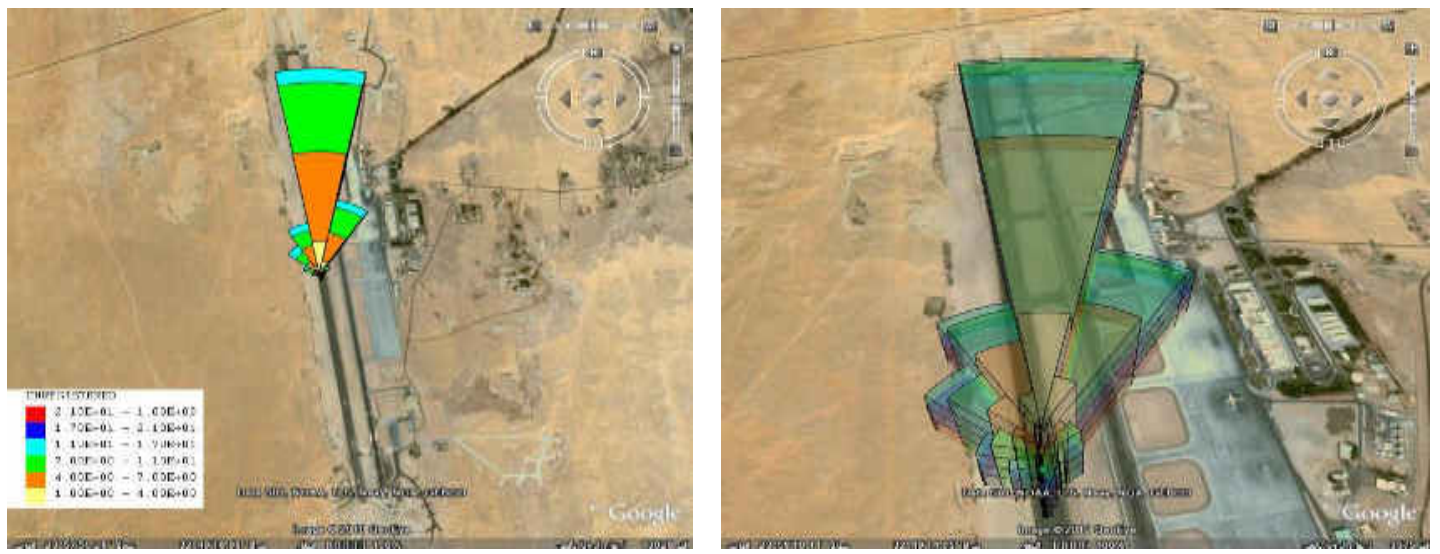

Fig.7. Print out of Aswan airport file produced with windRose PRO.

Journal of Engineering Sciences, Assiut University, Faculty of Engineering, Vol. 41, No. 6, November, 2013, E-mail address: jes@aun.edu.eg 
Mahmoud Enieb Osman et al., The optimum airport runway orientation for different regions in Egypt, pp. $2126-2139$
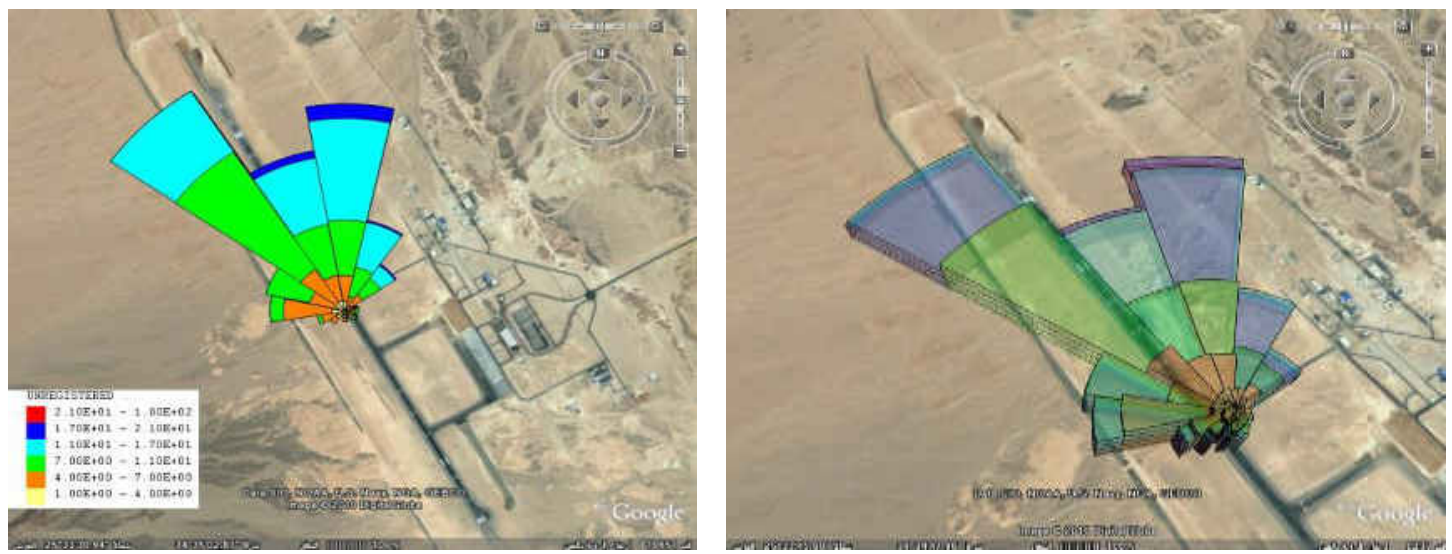

Fig.8. Print out of Al Nozha airport file produced with Wind Rose PRO.
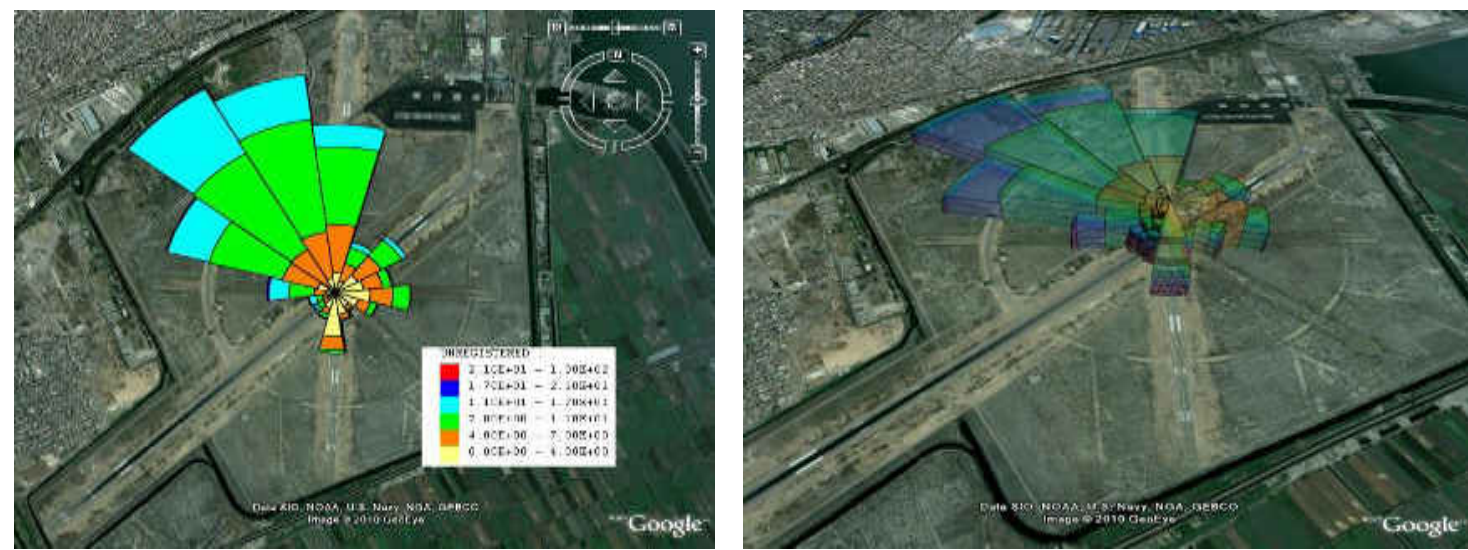

Fig.9. Print out of Marsa Alam airport file produced with Wind Rose PRO.

\subsection{Windrose II applications}

The manual Windrose II technique is used to estimate the optimum runway orientation for three cases study by analyzing wind summaries. The first wind summaries produced by processing the raw wind data of Aswan and Al Nozha SYNOP reports and the raw wind data produced by Marsa Alam airport organization with WRPLOT View software. The second wind summaries produced by the Egyptian meteorological organization. The percentage of time and the direction of wind are marked in the proper sector of wind rose diagram. The transparent template designed for permissible cross wind 10 Knots is rotated about the center of the wind rose diagram until the direction of the center line yield the maximum percentage of wind coverage between the outer parallel lines. In Figure 10, it is found that the best runway orientation for the wind summary produced by processing the raw wind data of Aswan Synop reports with WRPLOT View software is 175/355 and computed wind coverage is $97.63 \%$. In Figure 11, it is found that the best runway

Journal of Engineering Sciences, Assiut University, Faculty of Engineering, Vol. 41, No. 6, November, 2013, E-mail address: jes@aun.edu.eg 
Mahmoud Enieb Osman et al., The optimum airport runway orientation for different regions in Egypt, pp. 2126 - 2139

orientation for the Aswan wind summary produced by the Egyptian meteorological organization is $175 / 355$ and computed wind coverage is $95.2 \%$. In Figure 12, it is found that the best runway orientation for the wind summary produced by processing the raw wind data of Al Nozha Synop reports with the WRPLOT View software is 145/325 and computed wind coverage is $95.3 \%$. In Figure 13, it is found that the best runway orientation for Al Nozha wind summary produced by the Egyptian meteorological organization is $145 / 325$ and computed wind coverage is $94.1 \%$. In Figure 14, it is found that the best runway orientation for the wind summary produced by processing the raw wind data produced by Marsa Alam airport organization with the WRPLOT View software is $160 / 340$ and computed wind coverage is $99.8 \%$. In Figure 15, it is found that the best runway orientation for the wind summary produced by the Egyptian meteorological organization is $175 / 355$ and computed wind coverage is $95.04 \%$.

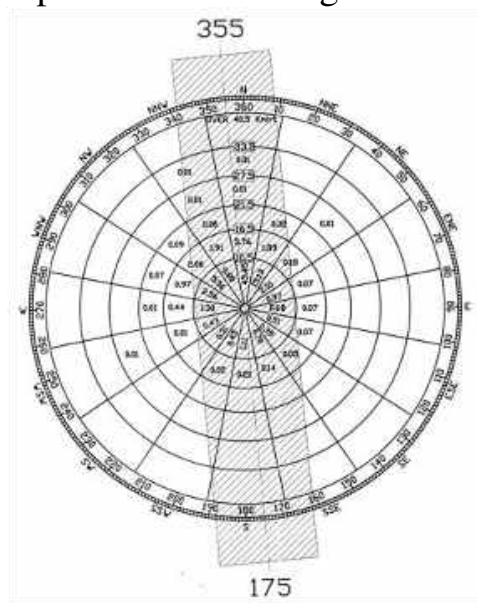

Fig. 10. Estimated orientation and wind coverage for Aswan airport runway by using WRPLOT View software.

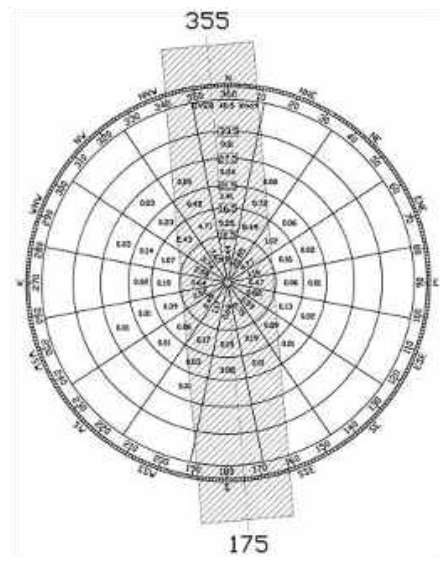

Fig. 11. Estimated orientation and wind coverage for Aswan airport runway by using Egyptian meteorological organization.

Journal of Engineering Sciences, Assiut University, Faculty of Engineering, Vol. 41, No. 6, November, 2013, E-mail address: jes@aun.edu.eg 
Mahmoud Enieb Osman et al., The optimum airport runway orientation for different regions in Egypt, pp. 2126 - 2139

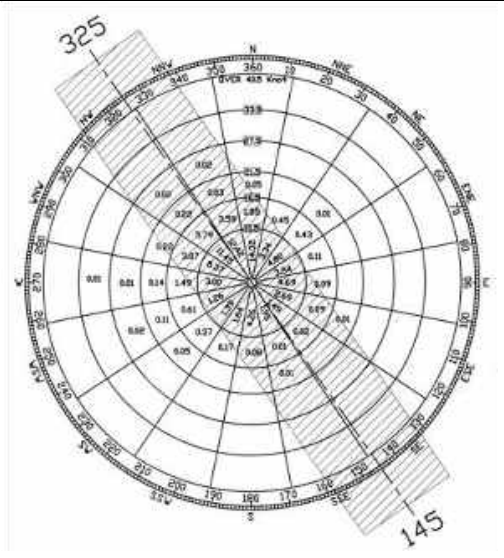

Fig. 12. Estimated orientation and wind coverage for Al Nozha airport runway by using WRPLOT View software.

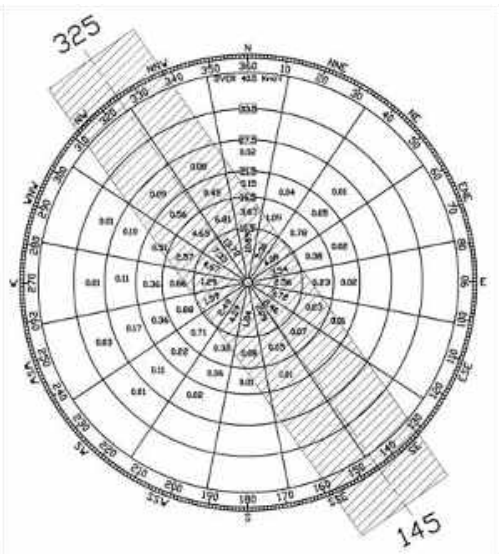

Fig. 13. Estimated orientation and wind coverage for Al Nozha airport runway by using Egyptian meteorological organization.

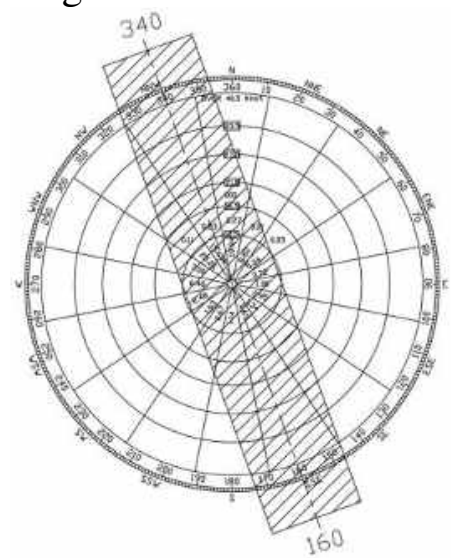

Fig. 14. Estimated orientation and wind coverage for Marsa Alam airport runway by using WRPLOT View software.

Journal of Engineering Sciences, Assiut University, Faculty of Engineering, Vol. 41, No. 6, November, 2013, E-mail address: jes@aun.edu.eg 
Mahmoud Enieb Osman et al., The optimum airport runway orientation for different regions in Egypt, pp. $2126-2139$

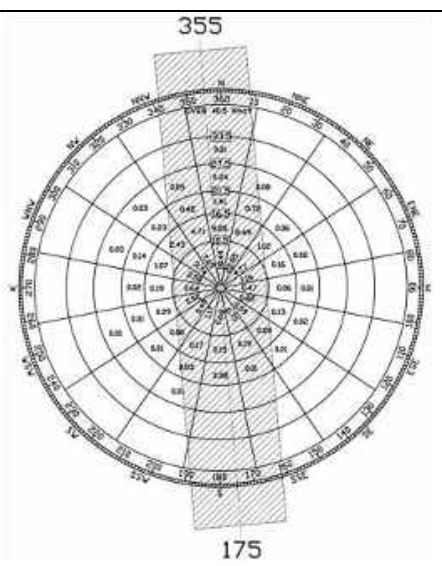

Fig. 15. Estimated orientation and wind coverage for Marsa Alam airport runway by using Egyptian meteorological organization.

\section{Conclusions}

The conclusions which can be drawn from this study are summarized as follows: 1-The wind data of Ogimet website SYNOP reports are matched with Egyptian Meteorological organization and capable of studding Egypt wind pattern.

2-WRPLOT View program is essential to analyze raw wind observations to estimate wind resultant vector, draw windrose and to produce wind summaries.

3-FAA airport design program and windrose PRO are capable of analyzing local wind data to find the optimum runway orientation but using FAA airport design program is preferred because windrose PRO program results have some non uniform changes.

4-The existing runways in Marsa Alam international airport and Aswan international airport have acceptable orientation but not the optimum while Al Nozha international airport has two existing runways with deferent non efficient orientations but the optimum solution is one with acceptable orientation.

5-The optimum two runway configuration for Al Nozha international airport has different directions from the existing.

6-After examining Egyptian surface wind pattern, it is found that the optimum solution for the most of Egypt regions is one direction while for Mersa Matruh and Port Said the optimum solution is two directions.

7-The existing runways in Assuit airport and Port Said airport have not efficient orientation so, second runway should be added.

8-The local cases studies are sensitive to the cross wind component between 10 Knots to 16 Knots and tailwind component from 0 Knots to 15 Knot.

\section{References}

[1] Mohamed R.N. Investigation in selecting the optimum airport runway orientation with special reference to Egyptian airports, M.Sc. Thesis, Civil Engineering Department, Assiut University, Assiut, Egypt, 2012.

[2] Horonjeff R. and F. X. Mckelvey. Planning and Design of Airports. McGraw-Hill Book Company, Third Edition, New York, 1986.

Journal of Engineering Sciences, Assiut University, Faculty of Engineering, Vol. 41, No. 6, November, 2013, E-mail address: jes@aun.edu.eg 
Mahmoud Enieb Osman et al., The optimum airport runway orientation for different regions in Egypt, pp. 2126 - 2139

[3] Kumar V. and S. Chandra. Air transportation planning and design. Galgotia Publications, Pvt. Ltd. First Edition, New Delhi, 1999.

[4] Circular A.C. 150/5300-13. Appendix 1, Airport design advisory Federal Aviation Administration. U.S. Department of transportation federal aviation administration. Flight Standards Service. Washington D.C. 29/9/1989.

[5] Antonio A. Trani, Virginia Tech, "Airport Runway Location and Orientation," "http://ebookbrowse.com/runway-orientation-pdf-d76460980"

[6] Wikipedia the free encyclopedia "Crosswind" "http://en.wikipedia.org/wiki/Crosswind"

[7] G.W.H. Van Es, P.J. van der Geest and T. M.H. Nieuwpoort "Safety aspects of aircraft operations in crosswind", National Aerospace Laboratory NLR (National Lucht- en Ruimtevaartlaboratorium), NLR-TP-2001-217, May 2001.

[8] National OceanicandAtmospheric Administration (NOAA) "Synop reports" "http://www.ogimet.com/"

[9] Wikipedia the free encyclopedia "Synop reports" "http://en.wikipedia.org/wiki/SYNOP"

[10] Federal Meteorological Handbook (FMH), Landstationsurfacesynopticcode FM 12-IX SYNOP, "Synop reports format" "http://atmo.tamu.edu/class/atmo251/LandSynopticCode.pdf"

[11] Circular AC 150/5300-13. Appendix 11. Airport designadvisory. Federal Aviation Administration. U.S. department of transportationfederalaviationadministrationflight standards service. Washington DC 29/9/1989.

[12] Enviroware company "WindRose PRO software" "http://www.enviroware.com/windrose.htm"

[13] Lakes Environmental Company "WRPLOT View software" "http://www.weblakes.com/products/wrplot/index.html"

[14] Ministry of civil aviation, "Aeronautical Information Publication” AIP A.R.E, Cairo, 13 Jan. 2011.

[15] ICAO and FAA, Detailed aero `111111111111nautical search engine, world aero data "Aswan airport" "http://worldaerodata.com/wad.cgi?id=EG90656\&sch=HESN"

[16] ICAO and FAA, Detailed aeronautical search engine world aero data"Al Nozha airport" "http://worldaerodata.com/wad.cgi?id=EG62850\&sch=HEAX"

[17] ICAO and FAA, Detailed aeronautical search engine, world aero data"Marsa Alam airport" "http://worldaerodata.com/wad.cgi?id=EG00005\&sch=HEMA"

Journal of Engineering Sciences, Assiut University, Faculty of Engineering, Vol. 41, No. 6, November, 2013,E-mail address: jes@aun.edu.eg 
الاتجاه الأمثل لمدارج المطارات فى مناطق مختلف بمصر

تبحث هذه الدراسة العربى تحديد الاتجاه الأمثل لمدرج المطار ات فى مناطق مختلفة بمصر و ذلك من تحليل الرياح

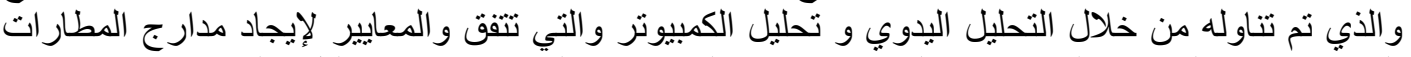

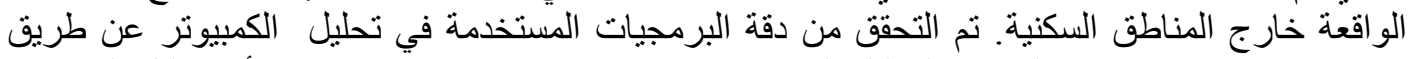

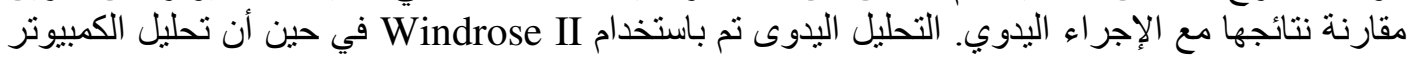

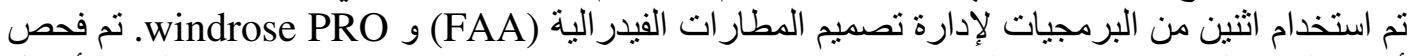
أنماط الرياح لعدد عشرين من المناطق في مصر باستخدام برنامجي WORPLOT و الإدئ

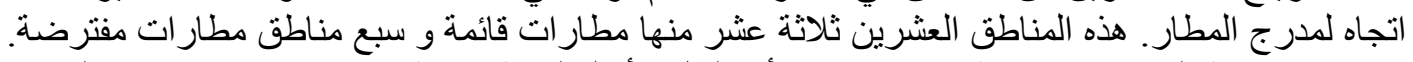

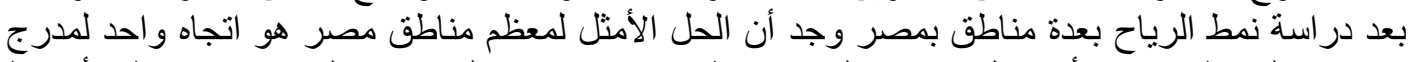

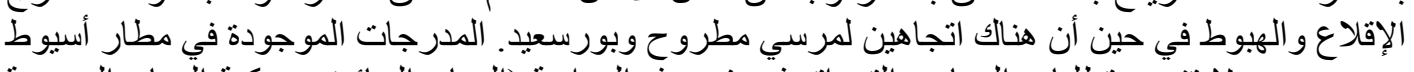
و بورسعيد ولا تفي بمتطلبات المعايير التي اتخذت في هذه الدين الدراسة (الرياح السائدة ومركبة الرياح الرياح العمودية

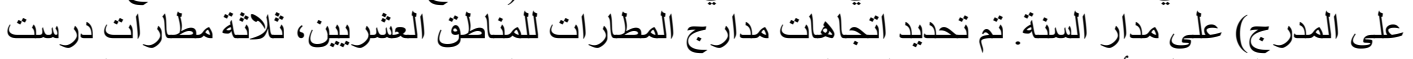

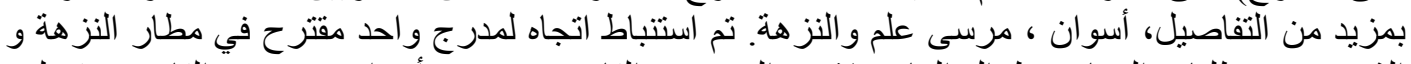

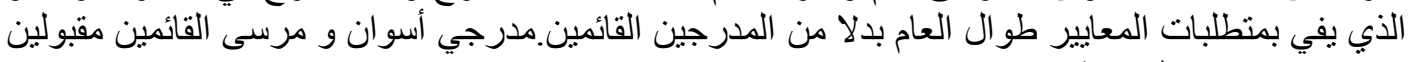
مع أعتبار معايير الدر اسة.

Journal of Engineering Sciences, Assiut University, Faculty of Engineering, Vol. 41, No. 6, November, 2013,E-mail address: jes@aun.edu.eg 